\title{
Cytotoxic T lymphocytes could contribute in COVID-19-induced passing anosmia
}

\section{Współudział cytotoksycznych limfocytów $T$ w anosmii w przebiegu COVID-19}

\author{
Marcin Zaremba, Agnieszka Płusa, Agnieszka Radowicz-Chil \\ Department of Clinical and Experimental Pathology, Institute of Medical Sciences, Jan Kochanowski University, Kielce, Poland \\ Head of the Department: Piotr Lewitowicz MD, PhD
}

Key words: anosmia, COVID-19, cytotoxic T lymphocytes.

Słowa kluczowe: anosmia, COVID-19, cytotoksyczne limfocyty T.

\begin{abstract}
Several clinical reports have demonstrated a spectrum of neurological manifestations of COVID-19 patients with subsequent post-mortem neuropathological findings. The aim of the case description is to show spotty inflammatory lesions in the olfactory bulb, which could lead to passing anosmia. Microscopic examination showed severe ischaemia and microglial proliferation in the olfactory bulb region. We encountered the presence of perivascular infiltration of cytotoxic T lymphocytes (CD8). The COVID-19 pandemic brought us many new challenges concerning viral detection, transmission, abd spread, then clinical symptoms, and clinical outcome. It seems that cytotoxic $T$ response could be a causative factor not only in respiratory tract injury but also is involved in the neural system, but further studies are required.
\end{abstract}

\section{Streszczenie}

Doniesienia naukowe z ostatnich miesięcy pokazują zmiany patologiczne w badaniach sekcyjnych u pacjentów, u których występowały objawy neurologiczne w przebiegu COVID-19. Celem pracy było wykazanie obecności nacieków zapalnych w obrębie opuszki węchowej, które mogą prowadzić do utraty węchu. W badaniu histopatologicznym licznych wycinków mózgu stwierdzono cechy ostrego niedokrwienia i proliferacje komórek mikrogleju w rejonie opuszki węchowej. Wykonano dodatkowe barwienia immunohistochemiczne na obecność limfocy tów T (CD4 i CD8). Wykazano obecność cytotoksycznych limfocytów T (CD8) zlokalizowanych wokół naczyń krwionośnych. Wydaje się, że odpowiedź immunologiczna z cytotoksycznych limfocytów T może mieć związek nie tylko z uszkodzeniem układu oddechowego, lecz także ze zmianami obserwowanymi w ośrodkowym układzie nerwowym, co wymaga dalszych badań.

\section{Introduction}

Severe acute respiratory syndrome coronavirus (SARS-CoV)-2 is a novel virus that comes under the same family as SARS-CoV and MERS. Due to failure in its containment, it has spread globally since its emergence in 2019, which subsequently led the World Health Organization (WHO) to declare a pandemic. SARS-CoV-2 causes the coronavirus disease of 2019 (COVID-19), presenting with symptoms akin to flu, which are potentially serious in cases of high-risk individuals [1]. Not unlike other coronaviruses, SARSCoV-2 predominantly causes flu-like symptoms, i.e., cough, fever, and asthaenia [2]. Severe lung injury has been reported irrespective of patients' age, but the elderly and those suffering from multimorbidities are more likely to develop interstitial pneumonia, ARDS, and multiorgan failure causing severe acute respiratory failure and a high mortality rate. Even though these viruses most often affect the respiratory system, their potential neurotropism has been noted in experimental studies and case reports. In SARS-CoV-2 cases there have been reports of patients developing nausea, myalgia, headaches and faintness [3], impaired consciousness, hyposmia, and hypogeusia [4], all of which account for nervous system involvement.

SARS-CoV-2 has a spike protein surface unit 1 that has a high binding affinity to the human receptor angiotensin-converting enzyme 2 (ACE2) [3]. Increased ACE2 expression of lower respiratory tract epithelial cells promotes entry by means of fusion with the cell membrane $[5,6]$. ACE2 expression is a likely explanation behind the involvement of the medullary structures, but it does not reach this extent in the case of temporo-limbic involvement. ACE2 is strongly expressed in areas playing a significant role in respiratory cycle regulation, i.e., ventrolateral medulla and 
the nucleus of the tractus solitarius [7]. However, the virus's affinity for the olfactory bulb is believed to be mediated by another mechanism, the nature of which remains unidentified. In the case of rodents, transnasal exposure led to quick detection in areas with direct neuronal link to the olfactory bulb, i.e., the piriform and infralimbic cortex, basal ganglia, and the midbrain [8]. Prior studies have demonstrated that SARS-CoV and MERS, probably through inflammatory response or autophagy, lead to the upregulation of interleukin-1 (IL-1), IL-6, and tumor necrosis factor- $\alpha$ (TNF- $\alpha$ ) cytokine response, resulting in direct neuronal death in the respiratory centre in the medulla [8]. Further studies are necessary to determine whether such observations are applicable to the SARS-CoV virus.

\section{Aim}

The aim of the case description is to show spotty inflammatory lesions in the olfactory bulb, which could lead to passing anosmia.

\section{Case report}

A 62-year-old female patient was admitted to hospital in bad general condition showing severe dyspnoea and cyanosis. Real-time polymerase chain reaction (RT PCR) and 15-minute cassette tests were performed, and both results were SARS-CoV-19 positive. The chest computed tomography (CT) scan showed typical interstitial pneumonia with honeycomb pattern. According to the patient's family the patient complained of weakness and anosmia for the preceding week. Unfortunately, intense therapy proved ineffective, and the patient died during her first day after admission.

The autopsy report revealed severe pulmonary injury, such as diffuse alveolar damage (DAD) with severe hyaline membrane syndrome, pneumocytes II hypertrophy, and intra-alveolar haemorrhage.

\section{Neuropathological findings in central nervous system}

Routine tissue samples taken from the cortex, basal ganglia, hippocampus, midbrain, and cerebellum showed moderate to severe oedema and significant pericellular 'halo' around oligodendrocytes, typical for severe central nervous system (CNS) ischaemia. There was no sign of encephalitis or neurodegeneration. Our attention was focused on the olfactory bulb nerve sample, in which we noted microglia proliferation with the formation of small microglia nodules (Figure 1). We applied double chromogen (RED, DAB Ventana Roche Diagnostics) immunohistochemistry to detect lymphocyte CD4+ and CD8+ fractions. We observed a spotty perivascular cytotoxic T (CD8+) lymphocyte infiltration with lesser contribution of CD4+ lymphocytes (Figure 2). Interestingly, neuropil abnormalities with peculiar myelin figures were

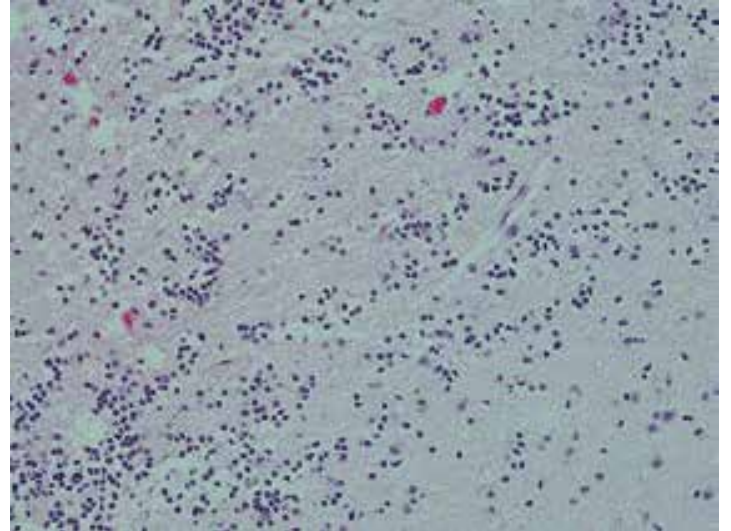

Figure 1. Microglia proliferation and microglia nodules in olfactory bulb sample $(\mathrm{H}+\mathrm{E}, 20 \times)$

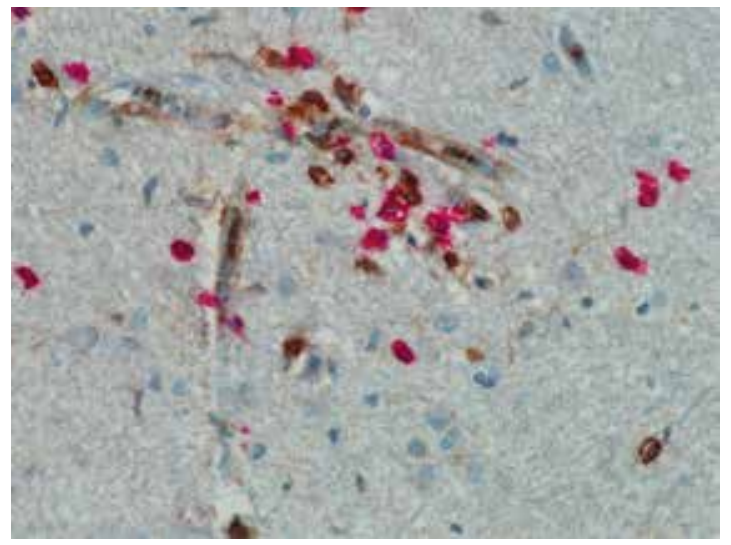

Figure 2. The olfactory bulb sample. Immunohistochemical assay with double chromogens (DAB\&Red). Red signals correspond to lymphocytes CD8+, brown to lymphocytes $\mathrm{CD} 4+$. Note, perivascular inflammatory response with CD8+ dominance (CD4/CD8 double immunohistochemistry 40x)

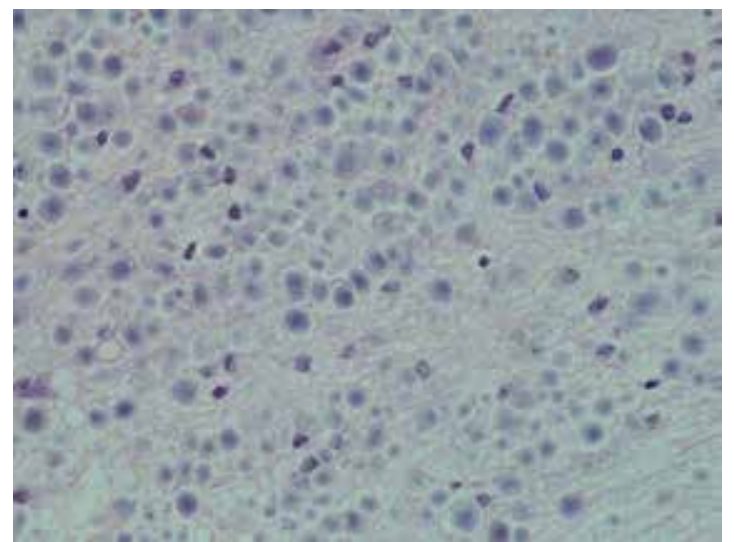

Figure 3. The olfactory bulb sample. Pericellular myelin loops with honeycomb pattern $(H+E, 40 x)$

observed. Pericellular myeline loops and pericellular myeline cap features were described as forming a 'chicken wire-like' pattern (Figures 3, 4). 


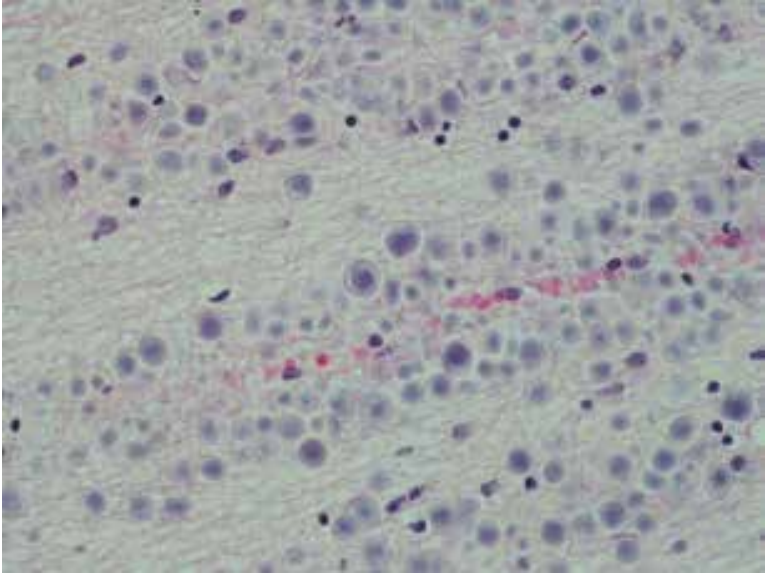

Figure 4 . The olfactory bulb. Myelin figures with pericellular caps $(H+E, 40 x)$

\section{Discussion}

Clinical data from 214 COVID-19 patients demonstrated neurological symptoms in $36.4 \%$ of cases. These symptoms included headaches, impaired consciousness, ataxia, acute cerebrovascular disease, seizures, hyposmia, hypogeusia, and neuralgias. The data suggests that patients with more severe systemic presentations were more likely to have neurological symptoms than those with milder forms of infection: acute cerebrovascular diseases (5.7\% vs. $0.8 \%$ ), impaired consciousness ( $14.8 \%$ vs. $2.4 \%)$, and skeletal muscle injury (19.3\% vs. 4.8\%) [4]. Neuromuscular symptoms caused by COVID-19 include developed weakness, sensorimotor peripheral nerve symptoms, and decreased deep tendon reflexes (DTRs), usually present after the third week of initial SARS onset [9]. The most common complaints were of hypogeusia and hyposmia [10]. It is still unclear how neurotransmission is changed by COVID-19. Last year provided an explosion of papers concerning Coronavirus biology, but information about neurodegeneration is still scarce [11-13]. The lethal case reported herein presents a typical respiratory tract injury complicated by severe ARDS and severe hypoxia. The antiviral cellular response we observed would be a causative factor for inhibition of neuron signal transduction. Being aware only of a singular case, we would like to report our findings, which need to be enhanced in additional cohort studies.

\section{Conclusions}

Cytotoxic $\mathrm{T}$ response might be a causative factor in respiratory tract injury, but it is also involved in the neural system. The myelin figures are unclear. It would be a specific pattern of neurodegeneration and postmortem artifact as well, so it requires further studies.

\section{Conflict of interest}

The authors declare no conflict of interest.

\section{References}

1. Pascarella G, Strumia A, Piliego C, Bruno F, Del Buono R, Costa F, Scarlata S, Agrò FE. COVID-19 diagnosis and management: a comprehensive review. J Intern Med 2020; 288: 192-206.

2. Wu D, Wu T, Liu Q, Yang Z. The SARS-CoV-2 outbreak: what we know. Int J Infect Dis 2020; 94: 44-48.

3. Wang D, Hu B, Hu C, Zhu F, Liu X, Zhang J, Wang B, Xiang H, Cheng Z, Xiong Y, Zhao Y, Li Y, Wang X, Peng Z. Clinical characteristics of 138 hospitalized patients with 2019 novel coronavirus-infected pneumonia in Wuhan, China. JAMA 2020; 323: 1061-1069.

4. Mao L, Jin $\mathrm{H}$, Wang $\mathrm{M}, \mathrm{Hu} \mathrm{Y}$, Chen $\mathrm{S}$, He Q, Chang J, Hong C, Zhou Y, Wang D, Miao X, LiY, Hu B. Neurologic manifestations of hospitalized patients with coronavirus disease 2019 in Wuhan, China. JAMA Neurol 2020; 77: 683-690.

5. Rothan HA, Byrareddy SN. The epidemiology and pathogenesis of coronavirus disease (COVID-19) outbreak. J Autoimmun 2020; 109: 102433.

6. Wan Y, Shang J, Graham R, Baric RS, Li F. Receptor recognition by the novel coronavirus from Wuhan: an analysis based on decade-long structural studies of SARS coronavirus. J Virol 2020; 94: e00127-20.

7. Doobay MF, Talman LS, Obr TD, Tian X, Davisson RL, Lazartigues E. Differential expression of neuronal ACE2 in transgenic mice with overexpression of the brain reninangiotensin system. Am J Physiol Regul Integr Comp Physiol 2007; 292: R373-R381.

8. Netland J, Meyerholz DK, Moore S, Cassell M, Perlman S. Severe acute respiratory syndrome coronavirus infection causes neuronal death in the absence of encephalitis in mice transgenic for human ACE2. J Virol 2008; 82: 7264-7275.

9. Tsai LK, Hsieh ST, Chang YC. Neurological manifestations in severe acute respiratory syndrome. Acta Neurol Taiwan 2005; 14: 113-119.

10. Xu XW, Wu XX, Jiang XG, Xu KJ, Ying LJ, Ma CL, Li SB, Wang HY, Zhang S, Gao HN, Sheng JF, Cai HL, Qiu YQ, Li LJ. Clinical findings in a group of patients infected with the 2019 novel coronavirus (SARS-Cov-2) outside of $\mathrm{Wu}$ han, China: retrospective case series. BMJ 2020; 368: m606.

11. Li Z, Liu T, Yang N, Han D, Mi X, Li Y, Liu K, Vuylsteke A, Xiang H, Guo X. Neurological manifestations of patients with COVID-19: potential routes of SARS-CoV-2 neuroinvasion from the periphery to the brain. Front Med 2020; 14: 533-541.

12. Vonck K, Garrez I, De Herdt V, Hemelsoet D, Laureys G, Raedt R, Boon P. Neurological manifestations and neuro-invasive mechanisms of the severe acute respiratory syndrome coronavirus type 2. Eur J Neurol 2020; 27: 1578-1587.

13. Fenrich M, Mrdenovic S, Balog M, Mrdenovic S, Balog M, Tomic S, Zjalic M, Roncevic A, Mandic D, DebeljakZ, Heffer M. SARS-CoV-2 dissemination through peripheral nerves explains multiple organ injury. Front Cell Neurosci 2020; 14: 229.

\section{Address for correspondence:}

Marcin Zaremba MD, $\mathrm{PhD}$

Department of Clinical and Experimental Pathology

Institute of Medical Sciences

Jan Kochanowski University

Kielce, Poland

E-mail: marcin.zaremba@ujk.edu.pl 